\title{
Mitigating the impact of swimming pools on domestic water demand
}

\author{
L Fisher-Jeffes ${ }^{1 *}$, G Gertse' and NP Armitage ${ }^{1}$ \\ 'Department of Civil Engineering, University of Cape Town, Private Bag X3, Rondebosch 7701, South Africa
}

\begin{abstract}
South Africa is a water-scarce country where the sustainable provision of water to its citizens is one of the most significant challenges faced. A recent study in Cape Town, South Africa, investigated the impact of residential swimming pools on household water demand and found that, on average, the presence of a swimming pool increased water demand by $8.85 \mathrm{k} \ell /$ month or $37.36 \%$. Should cities in South Africa wish to develop in a water sensitive manner - where water is treated as a scarce resource with economic value in all its competing uses - it will be vital to understand the impact of swimming pools on residential water demand. Should there be a significant increase in water demand attributable to the presence of a swimming pool on a property, it would highlight the need to consider whether it is acceptable for properties to use municipal water to fill them or top them up - especially in water-scarce/stressed areas. This paper describes a study undertaken in the Liesbeek River catchment, Cape Town, to investigate the impact that swimming pools have on domestic water demand. The results support the contention that properties with swimming pools use significantly more water than those without. This study estimated the additional demand resulting from swimming pools at between $2.2-2.4 \mathrm{k} \ell / \mathrm{month}$ or $7-8 \%$ of total water demand. The data also indicate that the presence of a swimming pool correlates with a higher indoor demand. The study shows the need to reduce the impact of swimming pools. This could include: pool covers to reduce evaporation, the recycling of backwash water, the use of rainwater to top up swimming pools, water use surcharges and, finally, appropriate regulation and enforcement to prevent the use of municipal water in swimming pools - especially during droughts.
\end{abstract}

Keywords: urban water management, swimming pools, water demand management

\section{INTRODUCTION}

South Africa is water scarce and the sustainable provision of water to its citizens is one of the most significant challenges facing the country. If a water crisis is to be averted, existing systems will need to be managed effectively. The Western Cape, in particular, (Jansen and Schulz, 2006) requires careful management of water, especially in urban areas such as the City of Cape Town (CoCT) where urbanisation is expected to result in further population growth, and, consequently, an increased demand for water.

A study undertaken by Siebrits (2012) investigated the impact of swimming pools on residential water demand in CoCT and found that they increase household water use by $37.36 \%$ or $8.85 \mathrm{k} \ell /$ month on average - with pools having a larger impact on the household water use of smaller properties. The implications of Siebrits' (2012) findings are significant, especially for more affluent suburbs where approximately $35 \%$ of the properties have swimming pools.

South Africa's Second National Water Resource Strategy (NWRS 2) (DWA, 2013) notes that large scale desalination is 'imminent', while simultaneously noting that it will be expensive at the coast and too costly to use inland. This raises the question as to whether it may be possible to delay or negate the need to implement desalination schemes by ensuring water is used in in a 'fit for purpose' manner. This study therefore aims

This paper was originally presented at the 2014 Water Institute of Southern Africa (WISA) Biennial Conference, Mbombela, 25-29 May 2014

* To whom all correspondence should be addressed.

e-mail:_lloyd.fisherjeffes@gmail.com to better understand the impact that pools have on residential water demand through the analysis of metered water demand records and end-use modelling. The study site was the Liesbeek River catchment, Cape Town, which has approximately 6200 single dwelling residential properties, approximately $35 \%$ of which have swimming pools. The metered water demand records were used to compare the total water demand (TWD) and outdoor demand (ODD) of properties both with pools and without. These differences were compared with the theoretical demand of pools determined by end-use modelling.

The results of this study may be used to inform municipalities about the impact on municipal water demand resulting from the construction of swimming pools. It could be that some municipalities should ban the use of potable water for filling and/or topping up swimming pools as this could lead to a significant saving of potable water and delay the need to invest in further water supply infrastructure such as dams and desalination plants. Such a ban would need to be enforced.

\section{METHODOLOGY}

\section{Case study catchment}

The Liesbeek River catchment, situated on the eastern slopes of Table Mountain in the City of Cape Town (CoCT) (Fig. 1), was selected for this study as it incorporates a diversity of land uses and there is a larger than normal amount of data available for the modelling and analysis of water demand. The catchment is about 2600 hectares in extent. The river itself is approximately $9 \mathrm{~km}$ long and is fed by numerous streams running down the eastern slopes of Table Mountain. The river has been, and continues to be, impacted by urbanisation. In total, approximately 


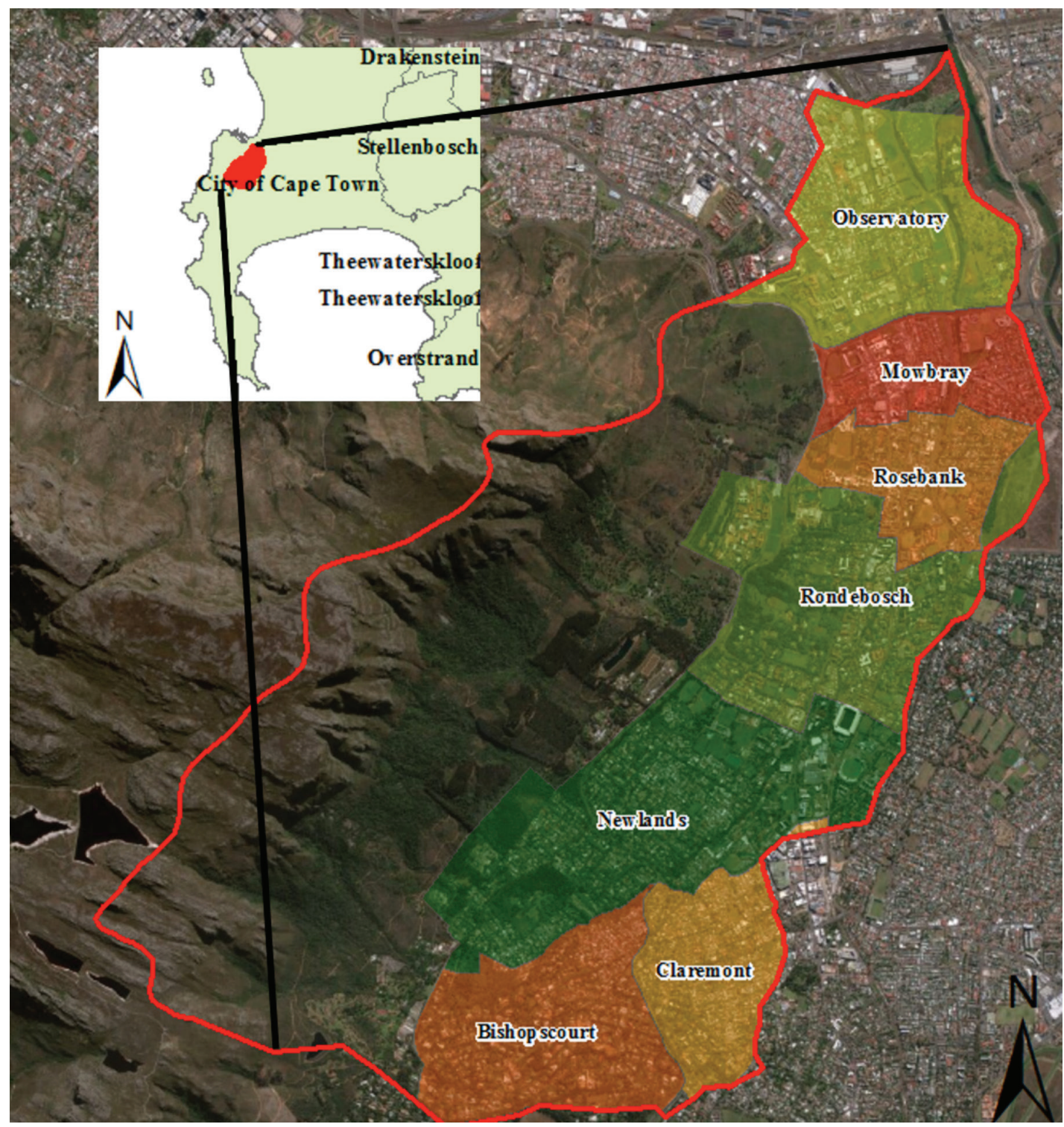

Figure 1

Liesbeek River catchment

$50 \%$ of the catchment is urbanised - with the balance taken up by Kirstenbosch Botanical Gardens, forestry plantations, and the Table Mountain National Park. The lower reaches of the river have the highest levels of urbanisation within the catchment.

While the Liesbeek River catchment has been inhabited since 1657 , it was only in the first half of the twentieth century that flooding started to become a serious problem as a result of increasing urbanisation. Consequently, between 1942 and 1962, large portions of the Liesbeek River were canalised (Brown and Magoba, 2009). Since 1990 there have been a number of initiatives to re-establish aquatic life and improve the aesthetics of the river (ibid.). These attempts have largely been localised around the banks of the river and have not targeted the catchment as a whole.

Six of CoCT's officially designated suburbs (CoCT, 2011) are either partially or entirely located within the catchment. There is a considerable difference between them. For example, Bishopscourt houses some of the wealthiest people in Cape Town whilst Observatory is occupied by much less wealthy people. Together they account for approximately 6200 single dwelling residential properties, $35 \%$ of which have swimming pools. The distribution of swimming pools is unequal in that the wealthier suburbs, such as Bishopscourt, have a higher proportion of swimming pools compared with the less wealthy suburbs, such as Observatory.

\section{Data collection and cleaning}

Traditionally, property (plot, stand, erf) areas have been used to estimate water demand in South Africa (e.g. CSIR, 2005). Jansen and Schulz (2006) found that property value and household income could also be considered as driving factors of residential water demand. This study investigated residential water demand based on municipal water meter records, property area, roof area, property value and household income.

Metered water demand, household income and property area data were acquired from GLS Consulting, with the permission of the CoCT Water Supply and Sanitation Department, from Statistics South Africa (Census 2011), and from the 
CoCT Strategic Information Department. The metered water demand data was for the year May 2010-April 2011. This data was selected as it was the only complete year for which billing records had been processed to interpolate a reading on the 25th of every month and any anomalies resulting from any inconsistencies in the meter readings removed. ArcGIS and Excel were then used to further filter the data to remove potentially unreliable data points. This included eliminating all properties where data was missing or where there were unexpected 'spikes' in the data (possibly due to a leak or incorrect measurement). The result was that 3600 of the $6200(60 \%)$ residential properties remained for further analysis.

In order to estimate the likely impact swimming pools have on water demand within the catchment it was necessary to collect detailed land-use data on each property. Orthophotographs obtained from the CoCT (CoCT, 2011) were used for this purpose (Fig. 2). Once all the data was captured, a further verification process was undertaken to check the accuracy of the data.

\section{Analysing the total water demand}

The total water demand (TWD) of households with swimming pools was then compared with the TWD of properties without swimming pools. Attempts were made to link these to 4 different factors: property area; roof area; property value and average net household income (using data at the small area level from Census 2011 (Stats SA, 2011)). In order to obtain large enough sample sizes, bands were established for each factor. The average TWD for each month was then calculated in each size band for households with and without swimming pools. This allowed for the contribution - positive or negative - of the 'presence' of swimming pools to be estimated. It is important to note that this does not necessarily equate exclusively to the additional demand associated with having a swimming pool but could also include other factors that correlate with the presence of a swimming pool.

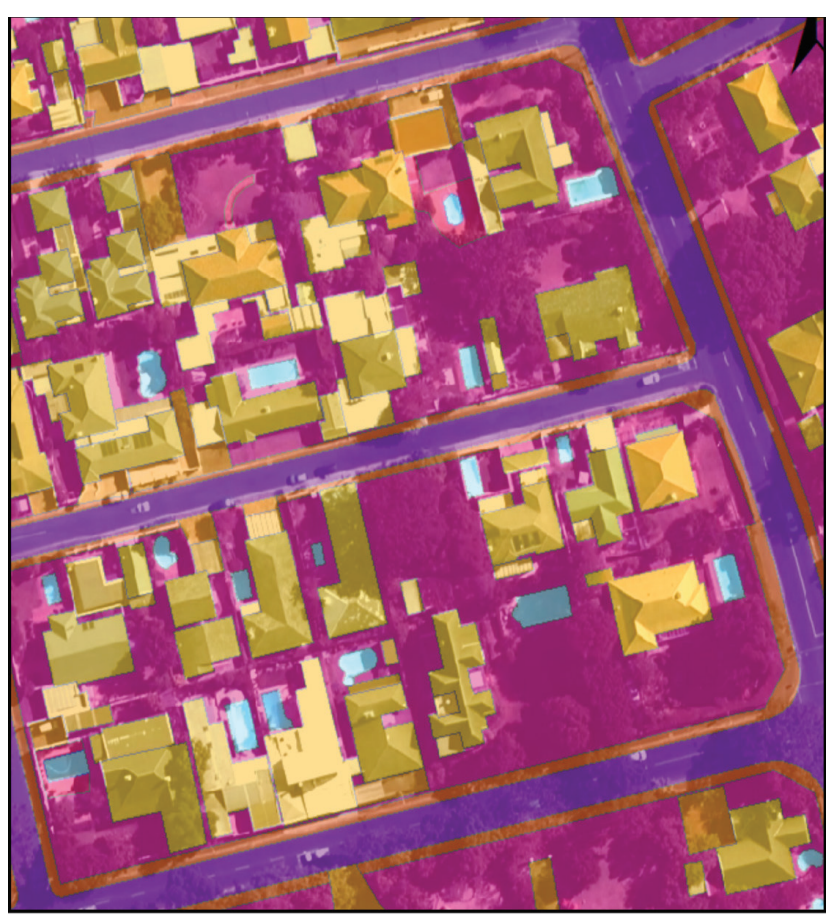

Figure 2

Captured roof and swimming pool areas

\section{Indoor/outdoor demand}

There has only been limited analysis of indoor and outdoor water demand in South Africa. Jacobs (2007) has presented some results showing a correlation between end-use demand modelling and measured data. Jacobs' (2007) study was however based on a small sample that does not represent the diversity in income, property area, climate etc. within the Liesbeek catchment. It was therefore necessary to find an alternative method to estimate the indoor demand. The assumption was therefore made that water demand during winter would largely equate to indoor use as there would be little in the way of garden watering (Cape Town is a winter rainfall area). This approach has been used elsewhere (e.g. Howe and Linaweaver, 1967; Aquacraft, 2011) and is supported by end-use modelling which suggests that outdoor irrigation is seasonal whilst indoor use is not. In order to select which months best reflected non-seasonal demand, end-use modelling was undertaken using the residential end-use model (REUM) (Jacobs and Haarhoff, 2004). This indicated that May-July would be the most appropriate months to consider as being equivalent to indoor demand only as there should have been no need for outdoor irrigation or need to fill pools, owing to the excess of precipitation over evaporation and other losses. The assumption was then made that the average indoor demand from May to July represents the average indoor demand for the entire year. Conversely, demand in the months of August to April was assumed to be a combination of both indoor demand (IDD) and outdoor demand (ODD) - with the latter resulting from garden irrigation and/or pool usage. The ODD for these months was then estimated by subtracting the estimated IDD from the TWD for each property.

\section{RESULTS AND DISCUSSION}

\section{Analysis of metered water demand}

Table 1 presents a correlation matrix linking 3 of the identified 4 factors that were potentially linked to household water demand in the Liesbeek River catchment. Van Zyl et al. (2008) showed that property size, property value and geographical location are dominant parameters influencing municipal water demand. A number of authors have shown that outdoor demand is the result of the local climate, size of outdoor area/ garden (that is maintained through irrigation) and the presence of a swimming pool (e.g. Mayer et al., 1999). The only variable not commonly considered is roof area, which was included in this study as it was considered a possible indicator of household income. Table 1 indicates that all the variables are related. The only variable not included in this correlation matrix is which suburb each property is in - because there was insufficient data. One significance of including 'suburb' as a factor is the large variation in evaporation and precipitation rates between suburbs in this particular catchment as a consequence of the orographic effect associated with Table Mountain.

\section{Property area}

The property areas within the catchment varied between 100 and $10000 \mathrm{~m}^{2}$. Typically, households with smaller property areas were less likely to have swimming pools whilst households with larger property areas were more likely to have swimming pools. This is to be expected as households on smaller 
properties are likely to have less disposable income. There is also less space for a pool.

This study focused on property areas between 100 and $2000 \mathrm{~m}^{2}$ as there were insufficient properties above $2000 \mathrm{~m}^{2}$ for statistical analysis. The properties were grouped in bands of $100 \mathrm{~m}^{2}$ to yield sufficient sample sizes (deemed to be at least 100 properties with and without pools). The average total water demand per month was then compared for households with and without swimming pools over the year for which data was available. Finally, the percentage by which the water demand of households with swimming pools exceeded households without swimming pools was computed for each property size band. The results are presented in Table 2 and Figure 3.

In Figure 3, values greater than zero indicate that, in a particular band, households with swimming pools used more municipal water on average than households without swimming pools, in the month in question. Conversely, percentage differences below zero indicate the opposite. The numbers indicate that properties with swimming pools typically use more water (on average, up to $20 \%$ or $1.1-6.4 \mathrm{kl} /$ month more over the year) than properties without swimming pools. What is particularly interesting is that, with the exception of properties

\begin{tabular}{|c|c|c|c|c|c|}
\hline \multicolumn{6}{|c|}{$\begin{array}{l}\text { TABLE } 1 \\
\text { Correlation matrix of variables that may be related to water demand }\end{array}$} \\
\hline & 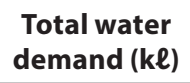 & Property area & $\begin{array}{l}\text { Total property } \\
\text { value ( } 2012 \text { ZAR) }\end{array}$ & Roof area $\left(\mathrm{m}^{2}\right)$ & Outdoor area $\left(\mathrm{m}^{2}\right)$ \\
\hline $\begin{array}{l}\text { Total water } \\
\text { demand }(k \ell)\end{array}$ & 1 & & & & \\
\hline Property area $\left(\mathrm{m}^{2}\right)$ & 0.54 & 1 & & & \\
\hline $\begin{array}{l}\text { Total property } \\
\text { value ( } 2012 \mathrm{ZAR})\end{array}$ & 0.55 & 0.8 & 1 & & \\
\hline Roof area $\left(\mathrm{m}^{2}\right)$ & 0.55 & 0.69 & 0.71 & 1 & \\
\hline Outdoor area $\left(\mathrm{m}^{2}\right)$ & 0.52 & 1 & 0.77 & 0.62 & 1 \\
\hline
\end{tabular}

\begin{tabular}{|c|c|c|c|}
\hline \multicolumn{4}{|c|}{$\begin{array}{c}\text { TABLE } 2 \\
\text { Difference in average TWD based on property area }\end{array}$} \\
\hline Property area $\left(\mathrm{m}^{2}\right)$ & $\begin{array}{c}\text { Average difference in } \\
\text { TWD (pools - no pools) } \\
\text { (kl) }\end{array}$ & $\begin{array}{l}\text { Average TWD for } \\
\text { properties with no pools } \\
(\mathrm{k} \ell)\end{array}$ & $\%$ increase in TWD for properties with pools \\
\hline $300-500$ & 4.4 & 22 & 20 \\
\hline $500-600$ & 2.5 & 26 & 9 \\
\hline $600-700$ & 1.1 & 31 & 4 \\
\hline $700-1000$ & 2.7 & 34 & 8 \\
\hline $1000-2000$ & 6.4 & 41 & 15 \\
\hline All properties & 8.2 & 27 & 30 \\
\hline
\end{tabular}

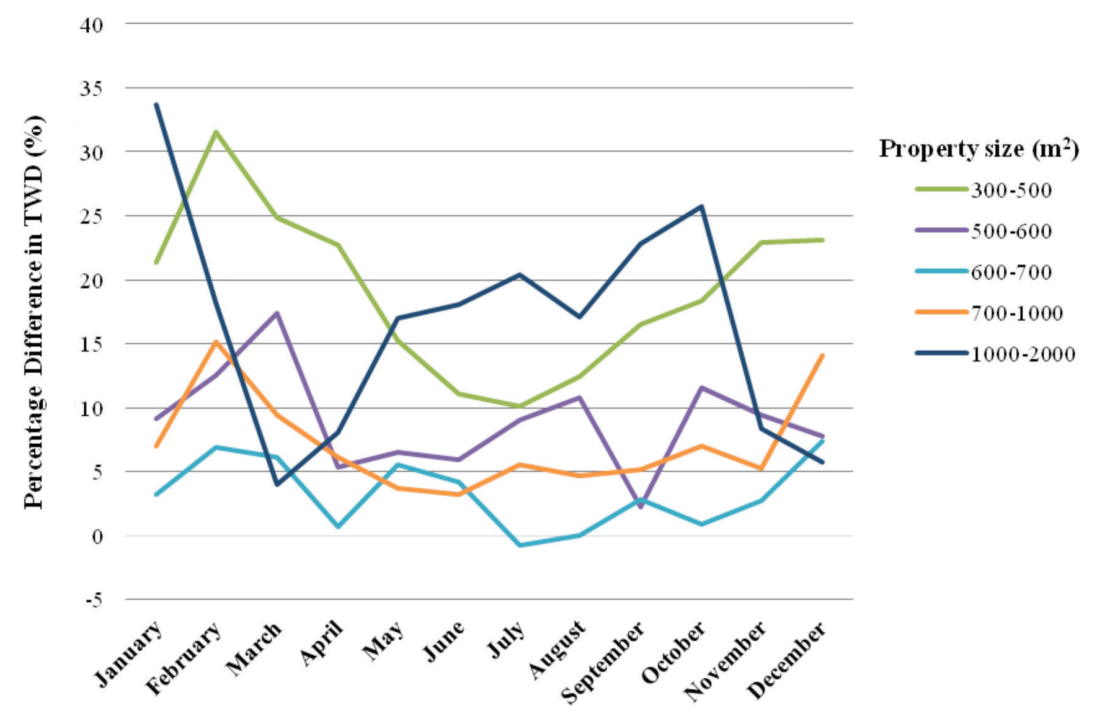

Figure 3

Difference (percentage) in average TWD based on property size 
in the $600-700 \mathrm{~m}^{2}$ range, properties with pools on average used more water throughout the year - even in winter, when there should have been no need for water to top up swimming pools. In particular, the presence of a pool correlates with a significant increase in water demand for properties in the 1000-2 $000 \mathrm{~m}^{2}$ range. With reference to Table 2, there is no obvious correlation between the property area and the impact of a swimming pool. As the area increases, the impact of the swimming pool first decreases to a minimum in the $600-700 \mathrm{~m}^{2}$ range, before increasing again. One plausible explanation for this relates to the relative impact of the swimming pool. On small properties, a swimming pool is likely to be the largest contributor to the ODD. As the property area increases, the relative contribution decreases as more water is devoted to maintaining the garden. Once the property exceeds $700 \mathrm{~m}^{2}$ though, the presence of a swimming pool becomes a measure of affluence - which is marked by an increased ODD through garden watering, perhaps facilitated by automatic sprinkler systems.

When all property areas are lumped together, the impact of a swimming pool is an average increase of $8.2 \mathrm{k} \ell /$ month or $30 \%$ - which is similar to that reported by Siebrits (2012). However, the significant differences between the various bands suggest that other factors are impacting the water demand, apart from - but linked to - the swimming pool.

\section{Property value}

As a proxy for household income, the various properties were grouped in various bands according to their total property value (CoCT, 2012), ensuring adequate sample sizes for properties with and without pools. Notably, no property (out of 234) valued at less than R1.1 million (2012 values) had a pool whilst only some $20 \%$ of properties valued at more than R5 million did not have a pool. This suggests that household income is a significant driver in determining the presence of a pool on a property. On the other hand, it was difficult to assess the impact pools have on properties valued outside of the range R1.1-5 million. Fortunately, $80 \%$ of the sample properties in the catchment fell within this range. The results are presented in Table 3 and Figure 4. They show a clear seasonal effect, with a peak in February (generally the hottest and driest month of the year). Overall, properties with pools used on average $13-25 \%(3.5-5.2 \mathrm{kl})$ more municipal water than properties without pools.

\section{Roof area}

One way of attempting to account for the combination of household income and household size (number of people) is to compare properties with and without pools using the roof area as a proxy. The assumption here is that roof area is closely linked to floor area for single storey developments, and floor area is likely to be strongly correlated with household income (ability to purchase the property) as well as household size (bigger households would likely live in bigger houses) - a significant driver of indoor demand. Properties with and without pools were again grouped, this time based on their roof area. The sample sizes for properties with roof areas less than $150 \mathrm{~m}^{2}$ or greater than $350 \mathrm{~m}^{2}$ were too small for meaningful analysis. The rest were grouped in intervals of $50 \mathrm{~m}^{2}$ and the

\begin{tabular}{|c|c|c|c|}
\hline \multicolumn{4}{|c|}{$\begin{array}{c}\text { TABLE } 3 \\
\text { Difference in average TWD based on property value }\end{array}$} \\
\hline $\begin{array}{l}\text { Property value } \\
\text { (2012 values) }\end{array}$ & $\begin{array}{c}\text { Average difference in } \\
\text { demand (pools - no pools) } \\
\text { (kl) }\end{array}$ & $\begin{array}{l}\text { Average TWD for } \\
\text { properties with no pools } \\
\text { (kl) }\end{array}$ & \% increase in TWD for properties with pools \\
\hline R1.1-2.5mil & 5.2 & 21 & 25 \\
\hline $\mathrm{R} 2.5-4 \mathrm{mil}$ & 3.5 & 28 & 13 \\
\hline R4-5 mil & 4.5 & 34 & 13 \\
\hline
\end{tabular}

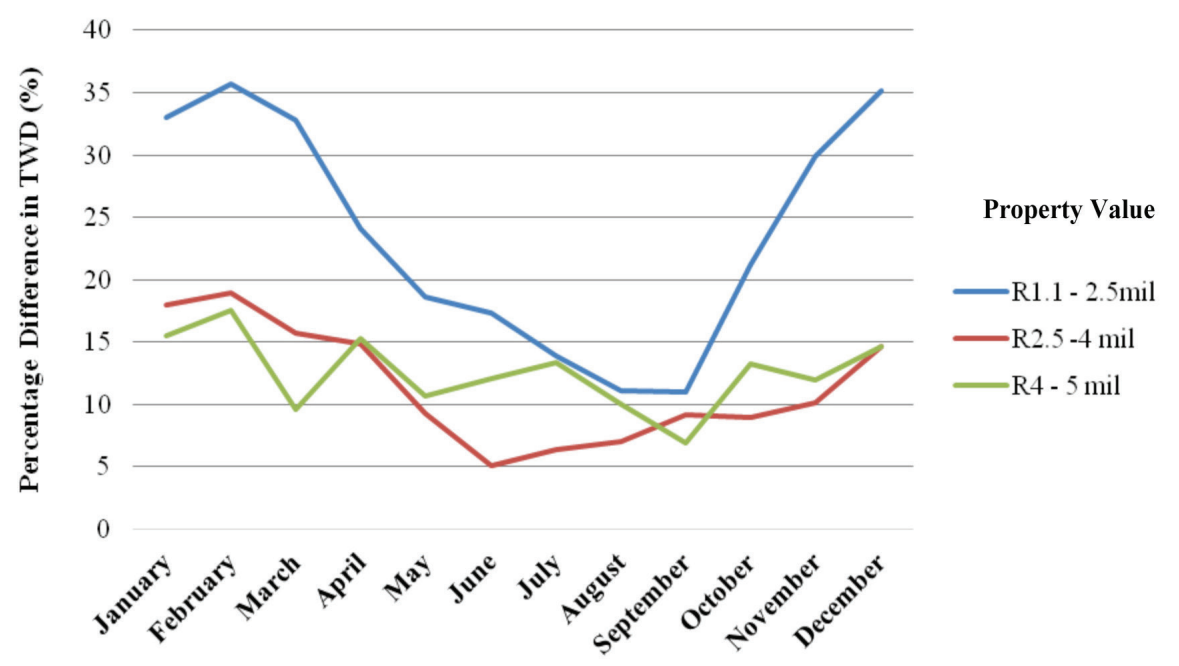

Figure 4

Difference (percentage) in average TWD based on property value 
results are presented in Table 4 and Figure 5. The results indicate that properties with pools generally use $1.5-7.7 \mathrm{k} \ell /$ month more municipal water than properties without, with a fairly pronounced seasonal pattern for all except the largest roof areas. For properties with roof areas between 150 and $300 \mathrm{~m}^{2}$, the presence of a pool results in an increase in municipal water demand of 6.5-7.7 kl/month. The relatively small difference in water demand between properties with and without pools for properties with roof areas between $300-350 \mathrm{~m}^{2}$ is hard to understand, but might have to do with the higher water usage generally associated with high-income households.

\section{Suburb}

Properties with and without pools were again grouped, this time based on which suburb they fell into. The assumption here was that suburbs tend to have similar property areas, levels of development, roughly the same micro climate (evaporation and precipitation), and similar levels of household income (ability to purchase the property). This approach has been used by Van $\mathrm{Zyl}$ et al. (2008). Only 3 suburbs could be considered as part of this analysis due to either too few $(<100)$ properties with pools (e.g. Observatory) or too few properties without pools (e.g. Bishopscourt). The results of this analysis are presented in Table 5 and Figure 6 . They show that the presence of a swimming pool consistently adds more than $20 \%$ to the municipal water demand - even in winter - up to a maximum of around $12.3 \mathrm{kl} / \mathrm{month}$.

\section{Outdoor Demand (ODD)}

A potential problem in the above analyses is that TWD incorporates IDD. IDD is dependent on a number of factors including, inter alia, household size and income. It is therefore likely that the results of the TWD analysis are distorted by the fact that presence of a swimming pool is likely to be associated with bigger household size and higher income - which means that a rise in ODD as a consequence of the presence of a swimming pool is likely to be paralleled by a rise in IDD (Danielson, 1979; Jacobs, 2007). The monthly ODD was thus calculated for each property (as discussed above), and the analyses (the link to: property area, property value, roof area, and suburb) repeated using the estimated ODD. The results are summarised in Table 6 . For all analyses the difference between properties with and without swimming pools is significantly reduced when compared to the TWD analyses. This provides support for the argument that the presence of a swimming pool is correlated with an increase in IDD. Whatever the reason, using TWD to compare properties with and without pools will likely lead to inflated estimates of the direct impact that a swimming pool has on household water demand.

The results indicated problems (e.g. inconsistent and sometimes negative values) when property area was used as the variable for assessing the difference between properties with and without pools. The significant differences between the various bands suggest that property area is not a good indicator.

When roof area and suburb were considered as the variables, the apparent difference in ODD was significantly higher

\begin{tabular}{|c|c|c|c|}
\hline \multicolumn{4}{|c|}{$\begin{array}{c}\text { TABLE } 4 \\
\text { Difference in average TWD based on roof area }\end{array}$} \\
\hline Roof area $\left(\mathrm{m}^{2}\right)$ & $\begin{array}{c}\text { Average difference in } \\
\text { demand (pools - no pools) } \\
(k \ell)\end{array}$ & $\begin{array}{l}\text { Average TWD for } \\
\text { properties with no pools } \\
(\mathrm{k} \ell)\end{array}$ & $\%$ increase in TWD for properties with pools \\
\hline 150-200 & 6.6 & 22 & 30 \\
\hline $200-250$ & 6.5 & 25 & 26 \\
\hline $250-300$ & 7.7 & 28 & 28 \\
\hline $300-350$ & 1.5 & 35 & 4 \\
\hline
\end{tabular}

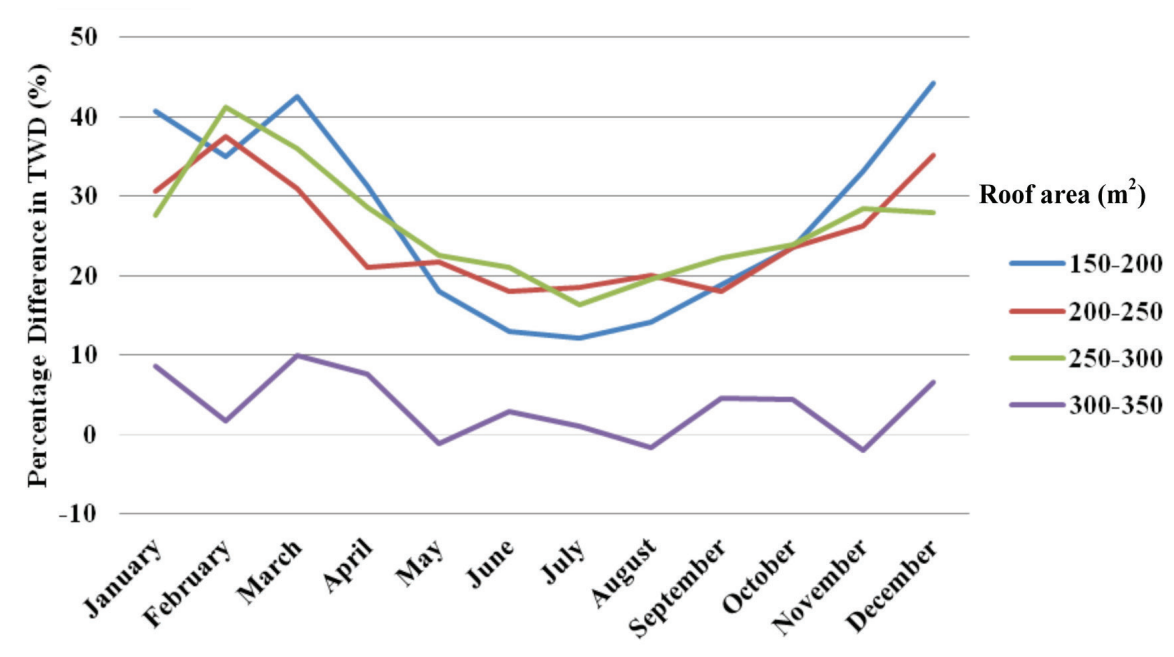

Figure 5

Difference (percentage) in average TWD based on roof area 


\begin{tabular}{|c|c|c|c|}
\hline \multicolumn{4}{|c|}{$\begin{array}{c}\text { TABLE } 5 \\
\text { Difference in average TWD based on suburb }\end{array}$} \\
\hline Suburb & $\begin{array}{c}\text { Average difference in } \\
\text { demand (pools - no pools) } \\
\text { (k } \ell)\end{array}$ & $\begin{array}{l}\text { Average TWD for } \\
\text { properties with no pools } \\
(\mathrm{k} \ell)\end{array}$ & $\%$ increase in TWD for properties with pools \\
\hline Newlands & 7.7 & 28 & 28 \\
\hline Claremont & 12.3 & 29 & 43 \\
\hline Rondebosch & 6.9 & 24 & 28 \\
\hline
\end{tabular}

60

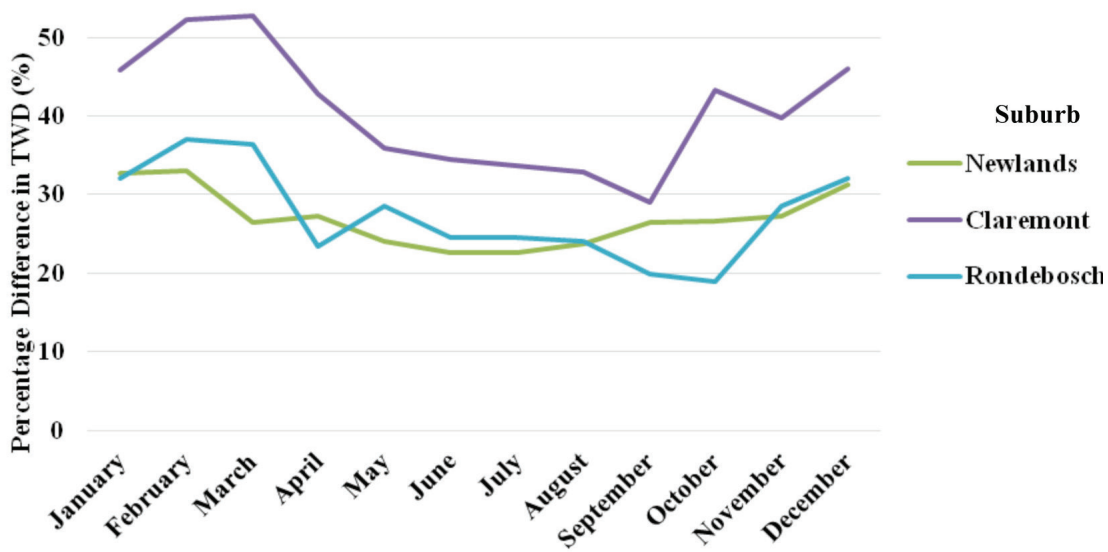

Figure 6

Difference (percentage) in average and median TWD based on suburb

\begin{tabular}{|c|c|c|c|c|c|}
\hline \multicolumn{6}{|c|}{$\begin{array}{l}\text { Table 6: } \\
\text { Difference in average ODD between properties with and without pools }\end{array}$} \\
\hline Variable & $\begin{array}{c}\text { Average } \\
\text { difference in ODD } \\
\text { (pools - no pools) } \\
\text { (kl) }\end{array}$ & $\begin{array}{l}\text { Average ODD for } \\
\text { properties with no } \\
\text { pools } \\
\text { (kl) }\end{array}$ & $\%$ increase in ODD & $\begin{array}{l}\text { Average TWD for } \\
\text { properties with no } \\
\text { pools } \\
\text { (kl) }\end{array}$ & $\begin{array}{c}\text { Difference in ODD } \\
\text { as a } \% \text { of TWD } \\
\text { for properties } \\
\text { without pools }\end{array}$ \\
\hline \multicolumn{6}{|l|}{ Property area } \\
\hline $300-500 \mathrm{~m} 2$ & 3.4 & 9 & 39 & 22 & 15 \\
\hline $500-600 \mathrm{~m} 2$ & 0.5 & 12 & 4 & 26 & 2 \\
\hline $600-700 \mathrm{~m} 2$ & -0.6 & 14 & -5 & 31 & -2 \\
\hline $700-1000 \mathrm{~m} 2$ & 1.9 & 17 & 11 & 34 & 6 \\
\hline $1000-2000 \mathrm{~m} 2$ & 3.2 & 21 & 15 & 41 & 8 \\
\hline \multicolumn{6}{|l|}{ Property value } \\
\hline R1.1-2.5 mil & 3.3 & 8 & 43 & 21 & 16 \\
\hline R2.5-4 mil & 2.3 & 12 & 19 & 28 & 8 \\
\hline R4-5 mil & 2.1 & 17 & 12 & 34 & 6 \\
\hline \multicolumn{6}{|l|}{ Roof area } \\
\hline $150-200 \mathrm{~m} 2$ & 4.9 & 9 & 57 & 22 & 30 \\
\hline $200-250 \mathrm{~m} 2$ & 4 & 10 & 38 & 25 & 26 \\
\hline $250-300 \mathrm{~m} 2$ & 4.3 & 12 & 36 & 28 & 28 \\
\hline $300-350 \mathrm{~m} 2$ & 0.4 & 17 & 3 & 35 & 4 \\
\hline \multicolumn{6}{|l|}{ Suburb } \\
\hline Newlands & 4 & 13 & 31 & 28 & 14 \\
\hline Claremont & 6.5 & 14 & 48 & 29 & 22 \\
\hline Rondebosch & 3.2 & 10 & 31 & 24 & 13 \\
\hline
\end{tabular}


than when property value was considered. A plausible explanation for this would be that properties with pools were using more water for outdoor irrigation. This was supported by an analysis of outdoor area that found that when using roof area and suburb as the variables, properties with pools had $25-100 \%$ more outdoor area than properties without. As a result, the potential additional ODD for garden irrigation distorts the results, and therefore suburb and roof area are not good variables for comparison.

An assessment of the outdoor area was undertaken when using property value as the variable for analysis. The results indicated that in the range R1.1-2.5 million, properties with pools had approximately $25 \%$ more outdoor area than those without. This is possibly because properties with pools are generally the more expensive ones and have larger gardens. In the ranges R2.5-4 million and R4-5 million, properties with pools had approximately $10 \%$ more outdoor area. As larger outdoor areas will likely lead to a higher ODD owing to the additional garden irrigation, it was therefore decided the focus should be on the large number of properties valued between R2.5-5 million where the additional outdoor area was minimal. Table 6 indicates that for these properties, swimming pools typically add between $2.1-2.3 \mathrm{k \ell} /$ month (approximately $6-8 \%$ ) to a household's water demand.

\section{SWIMMING POOL END-USE MODEL}

End-use modelling was used to give an alternative, more direct, assessment of swimming pool water demand. The REUM formulae presented in Jacobs and Haarhoff (2004) were used to estimate the volume of water that would be required to replenish the water that is lost to evaporation and backwashing and not replenished by precipitation. The calculations were undertaken on a monthly basis. It is important to note that this end-use modelling approach does not take account of water lost due to splashing. The formula used to model pool water demand was:

$$
A m m D D_{o, m, e}=\left(f_{m, e} \cdot s_{e}\right) \cdot \frac{\left(k_{m, e} \cdot P_{m}\right)-r_{m}}{d}+\left(a_{e} \cdot b_{e} \cdot c_{e} \cdot n\right)
$$

Where $o=$ outdoor; $m=$ monthly; $e=$ end-use; $f_{\mathrm{m}, \mathrm{e}}=$ pool cover factor; $s_{\mathrm{e}}=$ surface area of vegetation type or pool; $k_{\mathrm{m}, \mathrm{e}}=$ crop factor or pool factor; $p_{\mathrm{m}}=$ pan evaporation ratio; $r_{\mathrm{m}}=$ effective rainfall; $d=$ days in a month; $a_{\mathrm{e}}=$ presence of pool filter; $b$ = event filtering volume; $c_{\mathrm{e}}=$ frequency of use; $n=$ swimming pool area.

The equation used to model the effective rainfall $\left(r_{\mathrm{m}}\right)$ was:

$$
r_{m}=\left[\begin{array}{cc}
R & (R<25 \mathrm{~mm}) \\
(0.504-R+12.4 & (25 \mathrm{~mm} \leq R<152) \\
89 & (R \geq 152)
\end{array}\right]
$$

Where $R=$ monthly rainfall in $\mathrm{mm} /$ month and $p_{\mathrm{m},}, k_{\mathrm{m}, \mathrm{e}}, f_{\mathrm{m}, \mathrm{e}}$, and $s_{\mathrm{e}}$ are various factors contributing to outdoor demand as described below (Jacobs and Haarhoff, 2004):

- $\quad p_{\mathrm{m}}$ and $k_{\mathrm{m}, \mathrm{e}}$, monthly pan evaporation factor and monthly crop factor respectively, are climatological factors. Pan evaporation factors relate to the evapotranspiration of water in a given location in $\mathrm{mm} /$ month. Pool factors are dimensionless factors referring to evapotranspiration of water in comparison with an open body of water

- $f$ refers to the monthly pool cover factor. Pool cover factor refers to the use of a pool cover

- $s_{\mathrm{e}}$, surface area in $\mathrm{m}^{2}$ of the swimming pool or garden area.

It was assumed that every pool had a filter that would be used for backwashing. The event volume $\left(b_{\mathrm{e}}\right)$ was estimated to be between $100 \mathrm{l} /$ filter to a maximum of $600 \mathrm{l} /$ filter (Jacobs and Haarhoff, 2004; Mostert, 2013). Mostert (2013) suggested that weekly filtering is optimal, but that only filtering once a month is more common. Therefore the event frequency $\left(c_{\mathrm{e}}\right)$ was estimated to range from once a week to once a month. As a result, 2 analyses were undertaken: the first assuming a total monthly backwash of $400 \mathrm{l} /$ month (equivalent to filtering 100 $\ell$ four times per month, or $400 \ell$ once a month); and a second analysis assuming a total monthly backwash of $2400 \mathrm{l} / \mathrm{month}$ (equivalent to filtering $600 \mathrm{l}$ four times per month, $2400 \ell$ once a month, or some combination, including filtering and splashing).

The end-use modelling results are presented in Table 7. The results were averaged for each property value band (for properties between R2.5-5 million). They suggest that pools demand between $2.2-2.4 \mathrm{k \ell} / \mathrm{month}$ (for $400 \mathrm{l} / \mathrm{month}$ filtering) and $3.2-3.7 \mathrm{k} \ell /$ month (for $2400 \mathrm{l} / \mathrm{month}$ filtering).

Comparing the end-use modelled pool demand and the difference in metered ODD between properties with and without pools (Table 7), it is interesting to note that the modelled demand using $400 \mathrm{l} /$ month filtering is close to the calculated difference in ODD. This suggests that Mostert (2013) may be correct in suggesting that monthly filtering is the most common. A filtering rate of $2400 \mathrm{l} / \mathrm{month}$ gives values above those estimated by the ODD calculations. Therefore it seems reasonable to assume that end-use modelling using $400 \mathrm{l} / \mathrm{month}$ to account for filtering reflects the average swimming pool water demand and hence swimming pools add between 2.2-2.4 kl/ month to household water demand - which equates to a $7-8 \%$ increase in TWD and a $15-20 \%$ increase in ODD.

\section{CONCLUSIONS}

The study provides an insight into the potential impact that a swimming pool has on residential water demand. A comparison of swimming pool water demand predicted from end-use modelling with the difference in ODD between properties

TABLE 7

\begin{tabular}{|c|c|c|c|}
\hline Variable & $\begin{array}{l}\text { Filtering volume }(\ell / \\
\text { month) }\end{array}$ & $\begin{array}{l}\text { Modelled pool } \\
\text { demand (kl/month) }\end{array}$ & $\begin{array}{c}\text { Calculated difference in ODD between properties with } \\
\text { and without pools (kl/month) }\end{array}$ \\
\hline R2.5-4 mill. & 400 & 2.2 & 2.3 \\
\hline R4-5 mill. & 400 & 2.4 & 2.1 \\
\hline R2.5-4 mill. & 2400 & 3.5 & 2.3 \\
\hline R4-5 mill. & 2400 & 3.7 & 2.1 \\
\hline
\end{tabular}

Average pool demand calculated (end-use model) 
with and without pools gives similar values - in the region of $2.2-2.4 \mathrm{kl} /$ month which would represent an increase of 7-8\% in TWD and a 15-20\% increase in ODD when compared with properties that do not have pools. The fact that the presence of a swimming pool results in a much higher difference in TWD than ODD suggests that the presence of a pool is strongly correlated with other drivers of increased water demand apart from the swimming pool, for example, larger household size (families rather than individuals) and higher living standards. This probably accounts for the $8.85 \mathrm{kl} / \mathrm{month}$ additional swimming pool demand reported in Siebrits (2012) which was of a similar order to that estimated from the TWD comparison.

In order to prevent unnecessary use of water in water stressed areas, it is important that the additional demand that swimming pools add to household water use be reduced. This could be achieved through the promotion of pool covers to reduce evaporation, the installation of systems that recycle filter water, or the use of non-potable sources of water such as rainwater or groundwater, together with appropriate regulation and enforcement that prevents the use of potable municipal water to supplement swimming pools (especially during droughts). This could delay the need to invest in further water supply infrastructure such as dams and desalination plants.

\section{ACKNOWLEDGEMENTS}

While taking full responsibility for the processing and interpretation of the results published in this paper, the authors would like to acknowledge: CoCT Water Supply and Sanitation, CoCT catchment Stormwater and River Management, the South African Weather Service and GLS Consulting, for having provided valuable data and/or assistance. The authors are also grateful for the financial support of the South African Water Research Commission through Project K5/2071 and the Wilhelm Frank Trust..

\section{REFERENCES}

AQUACRAFT (2011) Analysis of water use in new single family homes. URL: http://www.allianceforwaterefficiency.org/WorkArea/ DownloadAsset.aspx?id=6020 (Accessed 3 September 2014).
BROWN C and MAGOBA R (2009) Rivers and Wetlands of Cape Town. WRC Report No. TT 376/08. Water Research Commission, Pretoria.

CoCT (CITY OF CAPE TOWN) (2011) City of Cape Town GIS Database: orthophotos and shapefiles. Strategic Information Department, City of Cape Town Metropolitan Municipality, Cape Town.

CoCT (CITY OF CAPE TOWN) (2012) City of Cape Town General Valuations Roll. City of Cape Town Metropolitan Municipality, Cape Town.

CSIR (2005) Guidelines for Human Settlement and Planning: Volume II. CSIR, Pretoria. ISBN: 0798854987.

DANIELSON LE (1979) An analysis of residential demand for water using micro time-series data. Water Resour. Res. 15 (4) 763-767.

DWA (DEPARTMENT OF WATER AFFAIRS, SOUTH AFRICA) (2013) National Water Resource Strategy. Water for an Equitable and Sustainable Future. June 2013 Second Edition. Department of Water Affairs, Pretoria.

HOWE C and LINAWEAVER F (1967) The impact of price on residential water demand and its relation to system design and price structure. Water Resour. Res. 3 (1) 13-31.

JACOBS HE (2007) The first reported correlation between end-use estimates of residential water demand and measured use in South Africa. Water SA 33 (4) 549-558.

JACOBS HE and HAARHOFF J (2004) Structure and data requirements of an end-use model for residential water demand and return flow. Water SA 30 (3) 293-304.

JANSEN A and SCHULZ C (2006) Water demand and the urban poor: a study of the factors influencing water consumption among households in Cape Town, South Africa. S. Afr. J. Econ. 74 (3) 593-609.

MAYER PW, DEOREO WB, OPITZ EM, KIEFER JC and DZIEGIELEWSKI B (1999) Residential end uses of water. American Water Works Association Research Foundation. URL: http:// www.waterrf.org/PublicReportLibrary/RFR90781_1999_241A.pdf (Accessed 3 September 2014).

MOSTERT JR (2013) Personal communication, 13 July 2013. Mr Jan Roberts Mostert, Tygerberg Pools cc., Kuilsrivier, Cape Town, Western Cape, South Africa, 7580.

SAVING WATER (2010) Go green with a pool side tank! http://www. savingwater.co.za/2010/12/29/12/go-green-with-a-poolside-tank/ (Accessed 26 February 2014).

SIEBRITS R (2012) Swimming pools and intra-city climates: influences on residential water consumption in Cape Town. Water SA 38 (1) 133-144.

STATS SA (2011) Census 2011. Statistics South Africa, Pretoria.

VAN ZYL H, ILEMOBADE A and VAN ZYL J (2008) An improved area-based guideline for domestic water demand estimation in South Africa. Water SA 34 (3) 381-392. 